DOI https://doi.org/10.30525/978-9934-26-117-6-22

\title{
СПЕЦИФІКА ВТІЛЕННЯ ІНТЕРТЕКСТУАЛЬНОСТІ В СУЧАСНІЙ КОМПОЗИТОРСЬКІЙ ПОЕТИЦІ (НА ПРИКЛАДІ ТВОРЧОСТІ СВГЕНА СТАНКОВИЧА)
}

\author{
Грібінснко Ю. О. \\ кандидат мистецтвознавства, \\ доиент кафедри історії музики та музичної етнографії \\ Одеська національна музична академія імені А. В. Нежданової \\ м. Одеса, Україна
}

Теорія інтертекстуальності формувалася, головним чином, в ході дослідження міжтекстових взаємодій в літературі. Однак, загальновідомо, що сфера побутування інтертекстуальності набагато ширше: вона має місце не тільки в вербальних текстах, але і в текстах, побудованих за допомогою інших знакових систем. Механізми інтертекстуальності діють у межах образотворчого і театрального мистецтва, архітектури, кінематографа, музики. Інтер-зв'язки, що становлять основу даного феномена, визначаються не тільки як «несвідома, автоматична або самодостатня ігрова цитація, а й спрямовані, осмислені, оціночні відсилання до попередніх текстів і художніх фактів» [6, с. 261].

Сучасні європейські науковці, серед яких Ц. Тодоров, У. Еко, М. Гаспаров, А. Жовківський, Ж. Женнет, Ю. Лотман, І І. Смирнов, 3. Тураєва, в своїх працях, звертаючись до явища інтертексту та інтертекстуальності, спираються на осмислення даного феномена М. Бахтіним і Ю. Кристевою. Остання як представниця французької літературознавчої школи при тлумаченні інтертекстуальності спиралася на установку культуролога-структураліста Р. Барта, висловлену ним в своєму есе «Смерть автора»: «Всякий текст $є$ між-текст по відношенню до якогось іншого тексту, але цю між-текстуальність не слід розуміти так, що у тексту є якесь походження; всякі пошуки «джерел» i «впливів» відповідають міфу про філіацію твору, текст ж утворюється 3 анонімних, невловимих i, разом 3 тим, вже читаних цитат - 3 цитат без лапок» [2, с. 418]. Обгрунтовуючи багатовимірність існування будь-якого тексту, французький культуролог підкреслював його нелінійність та визначав як «багатовимірний простір» [2, с. 338]. 
Л. Женні, один 3 послідовників Р. Барта, продовжуючи його роздуми, акцентує увагу на тому, що основною властивістю інтертекстуальності $є$ введення нового способу читання, який підриває лінеарність тексту та ставить перед вибором реципієнта - або продовжувати читання, не відрізняючи даний фрагмент тексту від інших, або повернутися до тексту - джерела цитацій [7, с. 276].

Провідні поняття теорії інтертекстуальності отримали розвиток в працях російських структуралістів і поструктуралістов, зокрема, Ю. Лотмана. Визначаючи межі тексту, цей науковець приходить до висновку про неминучість зв'язку будь-якого тексту 3 іншими, невідворотність діалогу і полілогу між текстами не тільки однієї епохи і не тільки тих, що належать до одного виду мистецтва, а й далеко віднесених один від одного по тимчасовій, жанровій або іншій шкалі. «Текст взагалі не існує сам по собі, він неминуче включається в будь-який (історично реальний або умовний) контекст... Та історикокультурна реальність, яку ми називаємо «художній твір», не вичерпується текстом. Сприйняття тексту, відірваного від його «внетекстового фону» неможливо» [4, с. 213].

I. Арнольд, залучаючи запропоновану Ю. Лотманом концепцію семіосфери, що забезпечує спадкоємність пізнання світу, вказує на особливу спрямованість інтертекстуального аналізу. Оскільки «досліджуючи інтертекстуальність... ми дивимося на те, що саме потрапило до тексту, що побачать в ньому читачі, і які асоціації ці включення можуть викликати» $[1$, с. 56]. Як система взаємодії текстів, сфера функціонування інтертекстуальності завжди передбачає взаємодію «свого» і «чужого» тексту, що дозволяє сприймати іiі як особливий спосіб включення людської свідомості в процес осмислення культурної дійсності. Зауважимо також, що задана в тексті інтертекстуальність $\epsilon$ авторською, тобто перед реципієнтами постає в готовому вигляді структурована мережа обмежень, накладених текстом на наше сприйняття. Тобто, ми можемо зробити висновок про те, що інтертекстуальність у другій половині XX - початку XXI століть стає методичної передумовою «прочитання» і інтерпретації (розуміння) культурних явищ і творів мистецтва (будь-якого тексту), одним із шляхів і способів передачі інформації.

У творчості Євгена Станковича, одного 3 найзначніших представників сучасної української музичної культури, «чуже слово» використовується в різноманітних формах і відсилає до різних традицій, історичних епох i авторських стилів. Яскраві приклади подібних включень ми знаходимо в музично-театральних творах композитора. Серед них в цьому плані виокремлюється один з гоголівських балетів 88 
Євгена Федоровича - «Ніч перед Різдвом», створений в традиції пастіччо. Дана жанрова модель, що грунтується на принципі синтезу запозиченого матеріалу, дозволила Є. Станковичу об'єднати різні, а часом й зовсім протилежні, стильові пласти. Для створення як гротескних, гумористичних, так ліричних ліній композитор використовує ряд цитат i алюзій, багато 3 яких, як вказує сам Свген Федорович, залишаються неідентифіковані публікою внаслідок їх глибинної трансформації. Серед цитацій, застосованих в балеті, колядки «Щедрик» та «Радуйся, земле», ряд відомих танцювальних композицій - циганочка, фокстрот «Розамунда», пасадобль «Ріо-Ріта», а також «Лебідь» К. Сен-Санса та популярні радянські пісні («Не кочегари», «Два кольори»). Наявність множинності різночасових включень як ділянок «підвищеної семантичної концентрації» (М. Арановський) стає принциповим для даного балету. Партитуру «Ночі перед Різдвом» можна назвати своєрідною «суперколлажною мозаїкою» (вираз А. Шнітке) гоголівського світу. За допомогою різкого зіставлення різних стильових моделей, свідомої деформації запозичень, пародійності і гротескності «чужого слова» композитор намагається розкрити амбівалентну суть художнього світу М. Гоголя.

До принципів «стильової гри» як «опосередкованої, амбівалентної репрезентації стильових знаків попередніх епох» [5, с. 16] С. Станкович в своїй творчості звертається постійно, ще з часів своєї «Симфонієти»: «одного з перших українських творів, де формування художньої концепції здійснено в умовах "гри стилями "(що позначено і в авторському підзаголовку - In modo collage)» [3]. У цьому творі, як і в наступних представлені різні форми включення «чужого слова»: від цитати і колажу (як різновиду цитування за А. Шнітке) до алюзії і стилізації. При цьому діапазон репрезентованих запозичень досить широкий. Застосування такого роду міжтекстових взаємодій допомагають в створенні композитором поліфонії закодованих смислів, для розкриття яких актуальною виявилась саме понятійна система музичної текстології.

\section{Література:}

1. Арнольд И. Семантика. Стилистика. Интертекстуальность. Реальность. СПбУ., 1999. 443 с.

2. Барт Р. Избранные работы: Семиотика. Поэтика. М.: Прогресс, 1989. 616 c.

3. Зинькевич Е. Рецепция Малера в украинском симфонизме. URL: https:/gnesin-academy.ru/wp-content/documents/nauka/muz_forum/ Zinkevich2. pdf 
4. Лотман Ю. Лекции по структуральной поэтике. Ю.М. Лотман и тартуско-московская семиотическая школа. М.: Гнозис, 1994. С. 10-257.

5. Коханик И. Между полистилистикой и метастилем: о стилевых исканиях украинских композиторов на рубеже XX-XXI веков. Київське музикознавство. Музикознавство у діалозі. Збірка статей. К, 2010. C. $12-20$.

6. Хализев В. Теория литературы. Учебник. М.: Высшая школа, 1999. $398 \mathrm{c}$.

7. Jenny L. La stratégie de la forme. Poétique, 1976. N 27. P. 257-281.

\title{
DOI https://doi.org/10.30525/978-9934-26-117-6-23
}

\section{ХОРЕОГРАФІЧНЕ МИСТЕЦТВО ЯК КУЛЬТОРОЛОГІЧНИЙ ФЕНОМЕН}

\author{
Кундис Р. Ю. \\ кандидат мистецтвознавства, \\ доиент кафедри режисури та хореографіі \\ Львівський національний університет імені Івана Франка \\ м. Львів, Украӥна
}

В сучасній світовій культурі мистецтво хореографії посідає одну 3 провідних позицій як в художньо-мистецькому, так i науковому аспекті. Цей феномен обумовлюється розширенням кордонів сприйняття ідейно-смислових значень як самого танцю, так і принципів, методів та підходів до його вивчення. Проблеми розвитку хореографічного мистецтва через культурологічний погляд привертали увагу багатьох українських хореологів минулого та сьогодення, серед яких варто визначити О. Чепалова та П. Фриза.

Мистецтво та творчість - важливі складові культури людства. Ще Р. Захаров зазначав, що «хореографія - самобутній вид творчої діяльності, підпорядкований закономірностям розвитку культури суспільства [1, с. 10]. Це означає, що як і будь-яке мистецтво, мистецтво хореографії необхідно розглядати у тісному взаємозв'язку з явищами, які відбуваються у суспільстві та визначаються вектором розвитку людства на певному етапі. Погоджуємось із думкою П. Фриза, який стверджує, що по завершенню певного часового періоду в художньо смисловій системі відбувається диференціація на зовнішній образ та 